\title{
Synthesis, X-ray Structures, and Reactivity of the First Bis(amino)metallastibanes and Bis(amino)metallabismuthanes
}

\author{
Anne-Marie Caminade* \\ Laboratoire de Chimie de Coordination du CNRS, Unité No. 8241 liée par conventions à l'Université Paul \\ Sabatier et à I'Institut National Polytechnique, 205 route de Narbonne, F-31077 Toulouse Cedex, France \\ Michael Veith* and Volker Huch \\ Institut für Anorganische Chemie der Universität, Im Stadtwald, D-6600 Saarbrücken, West Germany \\ Wolfgang Malisch*
}

Institut für Anorganische Chemie der Universität Würzburg, Am Hubland, 0-8700 Würzburg, West Germany

Received September 12, 1989

The reaction of $\mathrm{Me}_{2} \mathrm{Si}(\mathrm{N}-t \cdot \mathrm{Bu})_{2} \mathrm{ECl}(\mathrm{E}=\mathrm{Sb}, \mathrm{Bi})$ with $\mathrm{NaM}(\mathrm{CO})_{n} \mathrm{Cp}\left(\mathrm{M}=\mathrm{Fe}, \mathrm{Mo}, \mathrm{W} ; \mathrm{Cp}=\eta^{5}-\mathrm{C}_{5} \mathrm{H}_{5}\right)$ affords metallastibanes and bismuthanes, $\mathrm{Cp}(\mathrm{CO})_{n} \mathrm{ME}(\mathrm{N}-t-\mathrm{Bu})_{2} \mathrm{SiMe}_{2}(4 \mathrm{a}-\mathrm{c}, 5 \mathrm{a}-\mathrm{c})$. The structures of $4 c(E=S b, M=W)$ and $\mathbf{5 c}(E=B i, M=W)$ have been determined by X-ray crystallography. Both compounds are isotypic and isostructural and crystallize in the triclinic space group with $a=7.030$ (9) $\AA, b=10.51(1) \AA, c=16.22(2) \AA, \alpha=94.1(1)^{\circ}, \beta=90.4(1)^{\circ}, \gamma=104.9(1)^{\circ}, Z=2$ for $4 c$ and $a=7.014$ (9) $\AA, b=10.57$ (1) $\AA, c=16.25$ (2) $\AA, \alpha=94.1(1)^{\circ}, \beta=90.1(1)^{\circ}, \gamma=104.6(1)^{\circ}, Z=2$ for 5c. The E-W $\sigma$-bond lengths are 3.010 (1) $\AA$ for $\mathrm{E}=\mathrm{Sb}$ and 3.082 (1) $\AA$ for $\mathrm{E}=\mathrm{Bi}$. The reaction of the antimony derivatives with $\mathrm{Fe}_{2}(\mathrm{CO})_{9}$ yields $\left[\mathrm{Fe}(\mathrm{CO})_{4}\right] \mathrm{Cp}(\mathrm{CO})_{n} \mathrm{MSb}(\mathrm{N}-t-\mathrm{Bu})_{2} \mathrm{SiMe}_{2}(6 \mathrm{a}-\mathrm{c})$ as a result of the complexation of the antimony lone pair. The crystal structures of $6 a(M=F e)$ and $6 b(M=M o)$ have been determined. $6 a$ crystallizes in the monoclinic space group with $a=10.399$ (9) $\AA, b=16.76$ (2) $\AA, c=15.74$ (1) $\AA, \beta=94.16$ $(6)^{\circ}$ and $Z=4$. Both $\mathrm{Sb}-\mathrm{Fe}$ bond lengths are almost similar: 2.547 (1) $\AA$ for the covalent bond and 2.530 (1) $\AA$ for the dative bond. $6 \mathrm{~b}$ crystallizes in the monoclinic space group with $a=12.305$ (7) $\AA, b=13.812$ (7) $\AA, c=16.75$ (1) $\AA, \beta=99.03(5)^{\circ}$, and $Z=4$. The Sb-Mo covalent bond length is 2.871 (1) $\AA$ and the $\mathrm{Sb}-\mathrm{Fe}$ dative bond 2.539 (1) $\AA$.

\section{Introduction}

Organometallic complexes of the main-group elements are attracting an increasing amount of interest. For example, a significant number of metallaphosphanes, $\mathrm{L}_{n} \mathrm{MPR}_{2}(\mathrm{M}=$ transition metal) have been synthetized and structurally characterized. ${ }^{1}$ However, few investigations deal with the analogous compounds of the heaviest group-15 elements, i.e., metallastibanes ${ }^{2}$ and metallabismuthanes. ${ }^{2 c, 3}$ Such derivatives have been known since $1964,{ }^{3 \mathrm{a}}$ but organic substituents of antimony and bismuth lack diversification as in most cases, alkyl or phenyl groups, sometimes halides, but no amino groups have been used. Moreover, only one structure, $\mathrm{PPh}_{3}(\mathrm{CO})_{3} \mathrm{CoBiPh}_{2}$, has

(1) For X-ray structures of $R_{2} P M$ compounds, see, for example: (a) Barrow, M. J.; Sim, G. A.; Dobbie, R. C.; Mason, P. R. J. Organomet. Chem. 1974, 69, C4. (b) Barrow, M. J.; Sim, G. A. J. Chem. Soc., Dalton Trans. 1975, 291. (c) Hutchins, L. D.; Duesler, E. N.; Paine, R. T. Organometallics 1982, 1, 1254. (d) Baker, R. T.; Whitney, J. F.; Wreford, S. S. Organometallics 1983, 2, 1049. (e) Ebsworth, E. A. V.; Gould, R. O.; Mc Manus, N. T.; Pilkington, N. J.; Rankin, D. W. H. J. Chem. Soc. Dalton Trans. 1984, 2561. (f) Bohle, D. S.; Jones, T. C.; Rickard, C. E F.; Roper, W. R. J. Chem. Soc., Chem. Commun. 1984, 865. (g) Malish, W.; Angerer, W.; Cowley, A. H.; Norman, N. C. J. Chem. Soc., Chem. Commun. 1985, 1811. (h) Arif, A. M.; Cowley, A. H.; Nunn, C. M. Pakulski, M.J. Chem. Soc, Chem. Commun. 1987, 994.

(2) (a) Cullen, W. R.; Patmore, D. J.; Sams, J. R.; Newlands, M. J.; Thompson, L. K. J. Chem. Soc., Chem. Commun. 1971, 952. (b) Malisch, W.; Panster, P. J. Organomet. Chem. 1974, 76, C7. (c) Malisch, W.; Panster, P. J. Organomet. Chem. 1975, 99, 421, and references therein. (d) Kaul, H. A.; Greissinger, D.; Luksza, M.; Malisch, W. J. Organomet. Chem. 1982, 228, C29. (e) Thum, G.; Ries, W.; Greissinger, D.; Malisch W. J. Organomet. Chem. 1983, 252, C67. (f) Wade, S. R.; Wallbridge, M G. H.: Willey, G. P. J. Organomet. Chem. 1984, 267, 271. (g) Schemm, R.; Malisch, W. J. Organomet. Chem. 1985, 288, C9.

(3) (a) Nesmeyanov, A. N.; Anisimov, K. N.; Kolobova, N. E.; Khan dozhko, V. N. Dokl. Akad. Nauk. SSSR 1964, 156, 383 (CA61; 7041d) (b) Shrauzer, G. N.; Kratel, G. Angew. Chem. 1965, 77, 130; Angew. Chem., Int. Ed. Engl. 1965, 4, 146. Schrauzer, G. N.; Kratel, G. Chem Ber. 1969, 102, 2392. (c) Cullen, W. R.; Patmore, D. J.; Sams, J. R. Inorg. Chem. 1973, 12, 867. (d) Panster, P.; Malisch, W. J. Organomet. Chem. 1977, 134, C32. (e) Calderazzo, F.; Poli, R.; Pellizzi, G. J. Chem. Soc., Dalton Trans. 1984, 2535 .

\section{Scheme I}

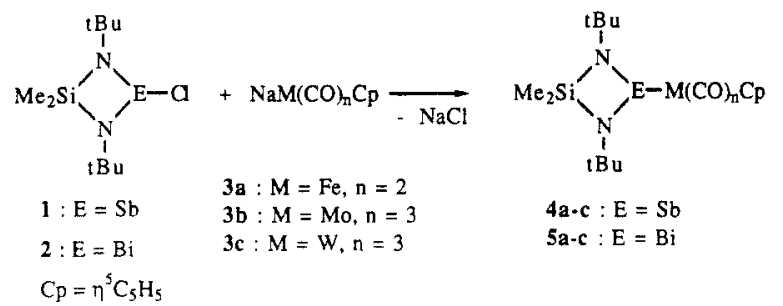

been determined by X-ray diffraction so far. ${ }^{3 e}$

This paper reports the synthesis of the first aminosubstituted metallastibanes and bismuthanes, their single-crystal X-ray diffraction characterization, and their behavior toward $\mathrm{Fe}_{2}(\mathrm{CO})_{9}$.

\section{Results and Discussion}

Synthesis of Metallastibanes and Metallabismuthanes. The reaction of $\mathrm{Me}_{2} \mathrm{Si}(\mathrm{N}-t-\mathrm{Bu})_{2} \mathrm{ECl}, 1(\mathrm{E}=\mathrm{Sb})$ and $2(\mathrm{E}=\mathrm{Bi}),{ }^{4}$ in hexane or benzene solution with $\mathrm{NaM}(\mathrm{CO})_{n} \mathrm{Cp}, 3 \mathrm{a}-\mathrm{c}(\mathrm{M}=\mathrm{Fe}, \mathrm{Mo}, \mathrm{W})$, at room temperature yields, by a nucleophilic metalation process, the corresponding cyclic bis(amino)metallastibanes, $\mathbf{4 a - c}$, and -bismuthanes, 5a-c (Scheme I).

${ }^{1} \mathrm{H}$ NMR spectroscopy shows that crude $\mathbf{4 a - c}$ and $\mathbf{5 a - c}$ are quantitatively obtained. Compounds $4 \mathbf{a}-\mathbf{c}$ and $\mathbf{5 b}-\mathbf{c}$ are isolated in $46-71 \%$ yield as extremely air- and moisture-sensitive powders or crystals. This sensitivity is related at least in part to the high lability of the $\mathrm{E}-\mathrm{N}$ bonds, which are easily cleaved to give bis(tert-butylamino)dimethylsilane. The most labile compound is $\mathbf{5 a}$, which has not been isolated but only characterized in solution. Its ${ }^{1} \mathrm{H}$ NMR spectrum exhibits four singlets in the range expected for such a compound: ${ }^{4} 0.19$ and $0.38 \mathrm{ppm}$ for the

(4) Veith, M.; Bertsch, B. Z. Anorg. Allg. Chem. 1988, 557, 7. 
Table I. 'H NMR and IR ${ }^{b}$ Data for Compounds 4a-c, 5a-c, and $6 a-c$

\begin{tabular}{|c|c|c|c|c|}
\hline \multirow[b]{2}{*}{ compound } & \multicolumn{3}{|c|}{${ }^{1} \mathrm{H}$ NMR, $\delta$} & \multirow[b]{2}{*}{ IR, $\nu(\mathrm{CO})$} \\
\hline & $\overline{\mathrm{Me}}$ & $\mathrm{tBu}$ & $\overline{C p}$ & \\
\hline$\overline{\mathrm{Me}_{2} \mathrm{Si}(\mathrm{N}-t-\mathrm{Bu})_{2} \mathrm{SbFe}(\mathrm{CO})_{2} \mathrm{Cp}}$ & $\begin{array}{l}0.35 \\
0.47\end{array}$ & 1.19 & 4.28 & $1982(\mathrm{~s}), 1933(\mathrm{~s})$ \\
\hline 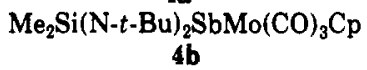 & 0.46 & 1.20 & 4.73 & $\begin{array}{l}1985(\mathrm{~s}), 1917(\mathrm{~m}) \\
1888(\mathrm{~s})\end{array}$ \\
\hline $\mathrm{Me}_{2} \mathrm{Si}(\mathrm{N}-t-\mathrm{Bu})_{2} \mathrm{SbW}(\mathrm{CO})_{3} \mathrm{Cp}$ & $\begin{array}{l}0.41 \\
0.45\end{array}$ & 1.19 & 4.77 & $\begin{array}{l}1987(\mathrm{~s}), 1916(\mathrm{~m}) \\
1883(\mathrm{~s})\end{array}$ \\
\hline$\underset{\mathbf{5 a}}{\mathrm{Me}_{2} \mathrm{Si}(\mathrm{N}-t-\mathrm{Bu})_{2} \mathrm{BiFe}(\mathrm{CO})_{2} \mathrm{Cp}}$ & $\begin{array}{l}0.19 \\
0.38\end{array}$ & 1.13 & 4.45 & $1976(\mathrm{~s}), 1929(\mathrm{~s})$ \\
\hline 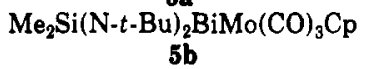 & $\begin{array}{l}0.24 \\
0.35\end{array}$ & 1.14 & 4.86 & $\begin{array}{l}1982(s), 1910(w) \\
1878(s)\end{array}$ \\
\hline$\underset{\mathbf{5 c}}{\mathrm{Me}_{2} \mathrm{Si}(\mathrm{N}-t-\mathrm{Bu})_{2} \mathrm{BiW}(\mathrm{CO})_{3} \mathrm{Cp}}$ & $\begin{array}{l}0.21 \\
0.35\end{array}$ & 1.14 & 4.95 & $\begin{array}{l}1983(\mathrm{~s}), 1909(\mathrm{w}) \\
1878(\mathrm{~m})\end{array}$ \\
\hline 68 & $\begin{array}{l}0.33 \\
0.59\end{array}$ & 1.32 & 4.53 & $\begin{array}{r}2039(\mathrm{~s}), 2012(\mathrm{~s}) \\
1977(\mathrm{br}), 1954 \\
(\mathrm{w}), 1924(\mathrm{br} s)\end{array}$ \\
\hline $6 b$ & $\begin{array}{l}0.42 \\
0.59\end{array}$ & 1.31 & 4.74 & $\begin{array}{c}2038(\mathrm{~m}), 2012(\mathrm{~s}) \\
1947(\mathrm{br} \mathrm{s}), 1927 \\
(\mathrm{~m}), 1911(\mathrm{w})\end{array}$ \\
\hline $6 c$ & $\begin{array}{l}0.42 \\
0.59\end{array}$ & 1.30 & 4.75 & $\begin{array}{c}2038(\mathrm{~m}), 2009(\mathrm{~s}) \\
1939(\mathrm{br} \mathrm{s}), 1921 \\
(\mathrm{~m}), 1906(\mathrm{w})\end{array}$ \\
\hline
\end{tabular}

a Spectra were recorded on a solution of the compound in $\mathrm{C}_{6} \mathrm{D}_{6}$. ${ }^{6}$ Hexane solution for $4 a-c$ and $5 a-c$, benzene for $6 a-c$.

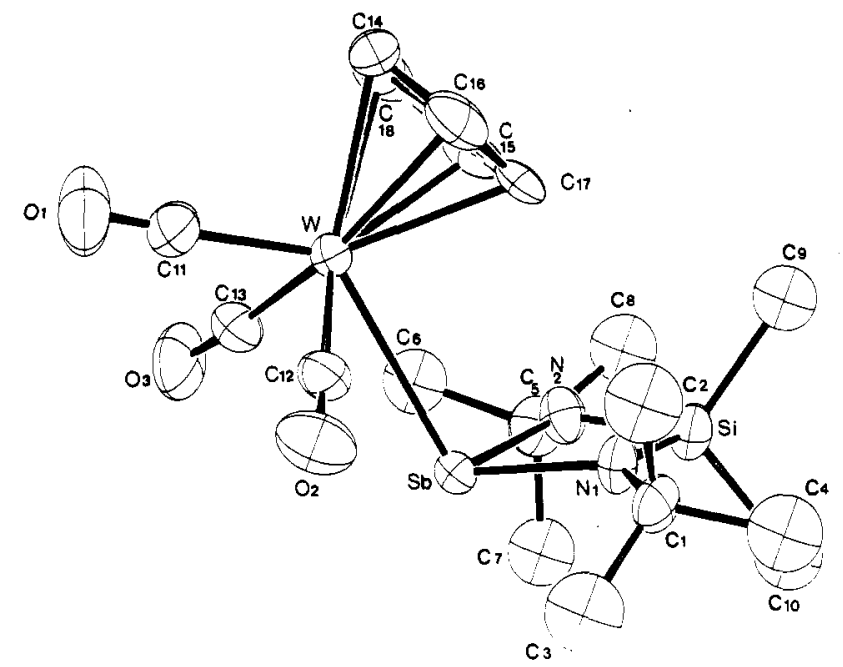

Figure 1. ORTEP drawing of 4c. Important bond distances $(\AA)$ and angles (deg): $\mathrm{SbW}=3.010(1) ; \mathrm{N}(1) \mathrm{Sb}=2.050(7) ; \mathrm{N}(2) \mathrm{Sb}$ $=2.066(7) ; \mathrm{N}(1) \mathrm{Si}=1.734(6) ; \mathrm{N}(2) \mathrm{Si}=1.733(8) ; \mathrm{N}(1) \mathrm{SbW}=$ 105.7 (2); N(2)SbW = $105.0(2) ; \mathrm{N}(1) \operatorname{SbN}(2)=74.3(3) ; \mathrm{N}(1) \operatorname{SiN}(2)$ $=91.6(3) ; \mathrm{SiN}(1) \mathrm{Sb}=96.9(3) ; \mathrm{SiN}(2) \mathrm{Sb}=96.4(3)$.

two magnetically unequivalent methyl groups, $1.13 \mathrm{ppm}$ for the two equivalent tert-butyl groups, and $4.45 \mathrm{ppm}$ for the $\eta^{5}$-bonded cyclopentadienyl ring. Furthermore, two intense carbonyl stretching vibrations are present in the IR spectrum of $\mathbf{5 a}$ as in the spectrum of the analogous isolated antimony derivative, 4a. Similarly, the IR spectra of $\mathbf{4 b , c}$ and $\mathbf{5 b}, \mathbf{c}$ exhibit three carbonyl stretching vibrations typical of a $C_{s}$ symmetry $\left(\mathrm{A}^{\prime}(1), \mathrm{A}^{\prime}(2)\right.$, and $\mathrm{A}^{\prime \prime}$; Table I).

To ascertain further the structure of the compounds of types 4 and 5 , X-ray structure determinations have been undertaken for $4 c$ and $5 c$.

X-ray Structural Analysis of $4 \mathrm{c}$ and 5c. The results of these determinations appear in Figures 1 for $4 \mathrm{c}$ and 2 for 5c, together with the atom-numbering protocol and selected bond lengths and angles. Pertinent crystallographic data are collected in Table II (compounds 4c and



Figure 2. ORTEP drawing of 5c. Important bond distances $(\AA)$ and angles (deg): $\mathrm{BiW}=3.082(1) ; \mathrm{N}(1) \mathrm{Bi}=2.17(1) ; \mathrm{N}(2) \mathrm{Bi}=$ $2.18(1) ; \mathrm{N}(1) \mathrm{Si}=1.75(1) ; \mathrm{N}(2) \mathrm{Si}=1.74(1) ; \mathrm{N}(1) \mathrm{BiW}=104.4$ (3); $\mathrm{N}(2) \mathrm{BiW}=103.1$ (4); $\mathrm{N}(1) \mathrm{BiN}(2)=71.4(4) ; \mathrm{N}(1) \mathrm{SiN}(2)=$ 93.5 (6); $\mathrm{SiN}(1) \mathrm{Bi}=96.9(5) ; \mathrm{SiN}(2) \mathrm{Bi}=96.9(5)$.

Table II. Summary of Crystal Data, Intensity Collection and Structure Solution and Refinement for $4 \mathrm{c}$ and $5 \mathrm{c}$

\begin{tabular}{|c|c|c|}
\hline & $4 c$ & 5c \\
\hline $\begin{array}{l}\text { formula } \\
\text { space group }\end{array}$ & $\begin{array}{l}\mathrm{C}_{18} \mathrm{H}_{29} \mathrm{~N}_{2} \mathrm{O}_{3} \mathrm{SbSiW} \\
P 1\end{array}$ & $\begin{array}{l}\mathrm{C}_{18} \mathrm{H}_{29} \mathrm{BiN}_{2} \mathrm{O}_{3} \mathrm{SiW} \\
P \overline{1}\end{array}$ \\
\hline st & triclinic & triclinic \\
\hline$\AA$ & $.030(9)$ & $7.014(9)$ \\
\hline$b, \AA$ & .5 & $10.57(1)$ \\
\hline$c, \AA$ & 6.2 & $16.25(2)$ \\
\hline$\alpha, \operatorname{deg}$ & 4.1 & 94.1 (1) \\
\hline$\beta, \operatorname{deg}$ & $0.4(1)$ & $90.1(1)$ \\
\hline$\gamma$, deg & $104.9(1)$ & $104.6(1)$ \\
\hline & 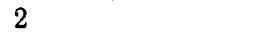 & 2 \\
\hline$V, \AA^{3}$ & 1155 & 1164 \\
\hline$d_{\text {calc }}, \mathrm{g} / \mathrm{cm}^{3}$ & 1.778 & 2.012 \\
\hline $\begin{array}{l}\text { cryst dimens, } \mathrm{mm}^{3} \\
\text { radiation }\end{array}$ & $\begin{array}{l}0.20 \times 0.15 \times 0.30 \\
\mathrm{M}_{o} \mathrm{~K} \alpha(0.71069 \AA)\end{array}$ & $\begin{array}{l}0.25 \times 0.25 \times 0.35 \\
\mathrm{M}_{o} \mathrm{~K} \alpha(0.71069 \AA)\end{array}$ \\
\hline$\mu, \mathrm{cm}^{-1}$ & 63.06 & 126.50 \\
\hline $\begin{array}{l}\text { no. of unique reflns } \\
\text { measd }\end{array}$ & 2958 & 2750 \\
\hline $\begin{array}{l}\text { no. of obsd reflns for } \\
\text { refinement }\end{array}$ & $2769\left(F_{\mathrm{o}}>3 \sigma\left(F_{\mathrm{o}}\right)\right)$ & $2136\left(F_{0}>3 \sigma\left(F_{0}\right)\right)$ \\
\hline $\begin{array}{l}\text { no. of variables used } \\
\text { in refinement }\end{array}$ & 221 & 220 \\
\hline$R$ & 0.050 & 0.044 \\
\hline & 0.052 & 0.045 \\
\hline$w=k /\left(\delta^{2} F+|g| F^{2}\right)$ & $k, 1.0 ; g ; 0.01013$ & $k, 0.6864 ; g, 0.00565$ \\
\hline $\begin{array}{l}\text { atoms refined } \\
\text { anisotropically }\end{array}$ & $\begin{array}{l}\text { W, Sb, Si, O, N, C1, } \\
\quad \mathrm{C} 5, \mathrm{C} 11-\mathrm{C} 13\end{array}$ & $\begin{array}{l}\text { W, Bi, Si, O, N, C1, } \\
\quad \text { C5, C11-C13 }\end{array}$ \\
\hline
\end{tabular}

5c are isotypic and isostructural).

Both crystal structures consist of distinct, well-separated monomers, which are in perfect agreement with our formulation. The four-membered rings $\mathrm{N}(1) \mathrm{SiN}(2) \mathrm{E}(\mathrm{E}=$ $\mathrm{Sb}$ or $\mathrm{Bi}$ ) are not as perfectly planar as in 1 and $2^{4}$ (dihedral angles between $\mathrm{N}(1) \operatorname{SiN}(2)$ and $\mathrm{N}(1) \mathrm{EN}(2)$ planes $(\mathrm{E}=$ $\mathrm{Sb}, \mathrm{Bi})$ are in $4 \mathrm{c} 9.7^{\circ}$ and in $5 \mathrm{c} 10.4^{\circ}$ ) and the nitrogen atoms are slightly pyramidal: the sum of angles around $\mathrm{N}(1)$ and $\mathrm{N}(2)$ is $358.4^{\circ}$ and $352.3^{\circ}$ for $4 \mathrm{c}, 357.9^{\circ}$ and $350.9^{\circ}$ for 5c. The two tert-butyl groups are in the cis position relative to the plane of the cycle, due to steric interactions between hydrogen atoms of the cyclopentadienyl ring and the tert-butyl groups $(4 \mathbf{c}, \mathrm{C}(2) \ldots \mathrm{C}(16)$, $\mathrm{C}(2) \ldots \mathrm{C}(17)=3.8 \AA ; \mathbf{5}, \mathrm{C}(2) \ldots \mathrm{C}(16)=3.8 \AA, \mathrm{C}(2) \ldots \mathrm{C}(17)$ $=4.0 \AA$. This indicates that the methyl group occupies the gap between $\mathrm{C}(16)$ and $\mathrm{C}(17))$. We believe that these steric repulsions are also responsible for the larger sum of the angles found at antimony $\left(285^{\circ}\right)$ or bismuth $\left(278.9^{\circ}\right)$ 
Scheme II

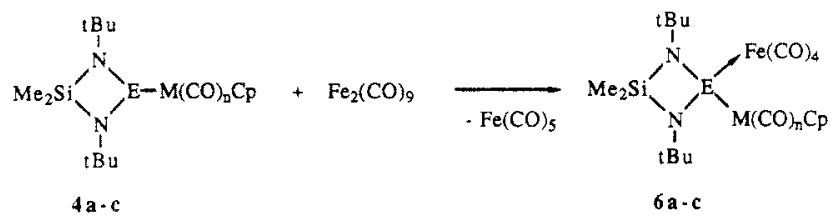

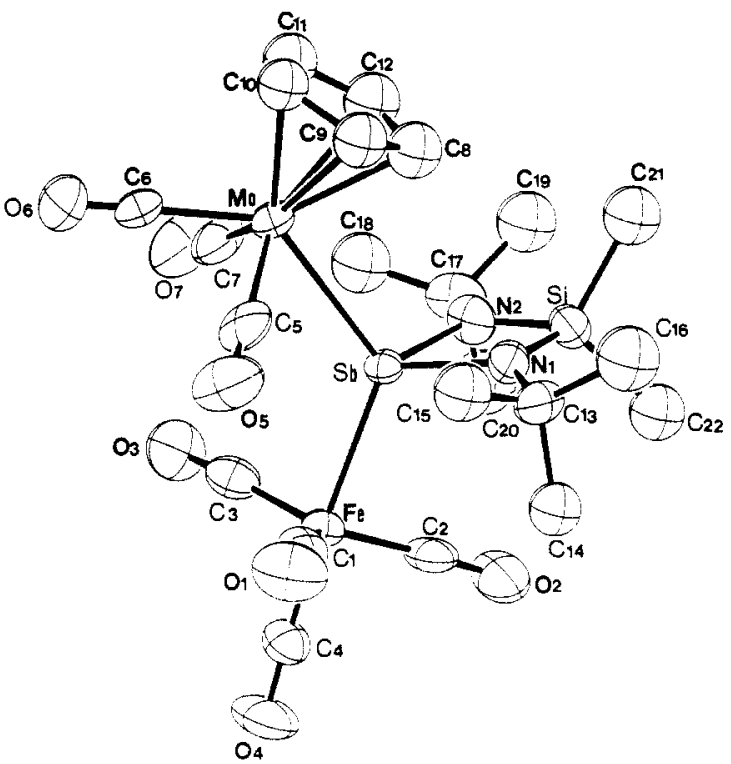

Figure 3. ORTEP drawing of 6 b. Important bond distances $(\AA)$ and angles (deg): $\mathrm{MoSb}=2.871$ (1); $\mathrm{FeSb}=2.539$ (1); N(1)Sb $=2.054(7) ; \mathrm{N}(2) \mathrm{Sb}=2.050(6) ; \mathrm{N}(1) \mathrm{Si}=1.736(7) ; \mathrm{N}(2) \mathrm{Si}=1.725$ (8); $\mathrm{MoSbFe}=122.8(1) ; \mathrm{N}(1) \mathrm{SbMo}=108.9(2) ; \mathrm{N}(2) \mathrm{SbMo}_{0}=$ 111.5 (2); $\mathrm{N}(1) \mathrm{SbFe}=115.0(2) ; \mathrm{N}(2) \mathrm{SbFe}=114.1$ (2); N(1)SbN(2) $=74.5(3) ; \mathrm{N}(1) \mathrm{SiN}(2)=91.7(3) ; \mathrm{SiN}(1) \mathrm{Sb}=96.6(3) ; \mathrm{SiN}(2) \mathrm{Sb}$ $=97.1(3)$.

with respect to $1\left(274.5^{\circ}\right)$ or $2\left(267.4^{\circ}\right)$.

To the best of our knowledge, 4c represents the first structurally characterized example of stibido ligands (and $5 \mathbf{c}$ the second for bismuthido ligands) terminally coordinated to transition-metal centers, and therefore direct comparisons of $\mathrm{E}-\mathrm{W}$ distances are not possible. The observed $\mathrm{E}-\mathrm{W}$ distances $(3.010 \AA$ for $\mathrm{E}=\mathrm{Sb}$ and $3.082 \AA$ for $\mathrm{E}=\mathrm{Bi}$ ), although much longer than those described in the literature for dative $\sigma$-bonds (e.g., 2.757 and $2.766 \AA$ for $\left[\mathrm{W}(\mathrm{CO})_{5}\right]_{2}\left[\mu-\mathrm{W}(\mathrm{CO})_{5}\right](\mathrm{SbPh})_{2}{ }^{5}$ and $2.851 \AA$ for $[\mathrm{W}$ (CO) $\left.\left.)_{5} \mathrm{BiMe}\right]\left[\mathrm{W}_{2}(\mathrm{CO})_{8} \mathrm{Bi}_{2}\right]\right),{ }^{6}$ are close to the sum of covalent radii of antimony or bismuth (1.40 and $1.46 \AA$, respectively) and of tungsten (1.611 $\AA$ ) obtained from $\mathrm{Cp}$ $(\mathrm{CO})_{3} \mathrm{~W}-\mathrm{W}(\mathrm{CO})_{3} \mathrm{Cp}^{7}$ In comparison to the chlorine compounds 1 and $2,{ }^{4}$ the $\mathrm{Si}-\mathrm{N}$ distances in $4 \mathrm{c}$ and $5 \mathrm{c}$ are of the same magnitude (1.73-1.75 $\AA$ ).

Complexation of Metallastibanes. When a benzene solution of metallastibanes $4 a-c$ is added to a benzene suspension of $\mathrm{Fe}_{2}(\mathrm{CO})_{9}$, the corresponding complexes $6 \mathrm{a}-\mathrm{c}$ are isolated in $59-62 \%$ yield as relatively air stable compounds (Scheme II).

The reaction of metallabismuthanes $\mathbf{5 a - c}$ under the same experimental conditions did not afford the corresponding metallabismuthane complexes. This illustrates the well-known decrease in the availability for bonding of

(5) Huttner, G.; Weber, U.; Sigwarth, B.; Scheidsteger, O. Angew. Chem. 1982, 94, 210; Angew. Chem., Int. Ed. Engl. 1982, 21, 215; Angew. Chem. Suppl. 1982, 411.

(6) Arif, A. M.; Cowley, A. H.; Norman, N. C.; Pakulski, M. J. Am. Chem. Sac. 1985, 107, 1062.

(7) Adams, R. D.; Collins, D. M.; Cotton, F. A. Inorg. Chem. 1974, 13, 1086

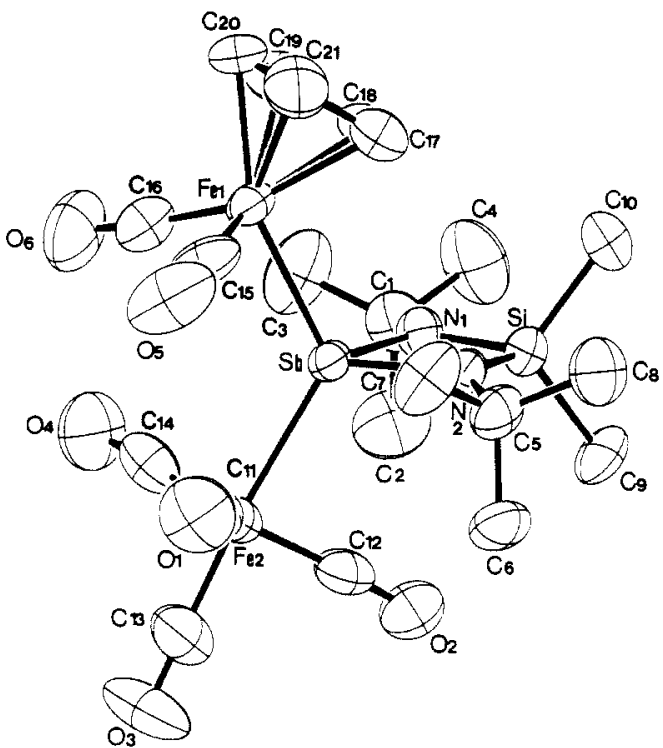

Figure 4. ORTEP drawing of 6a. Important bond distances $(\AA)$ and angles (deg): $\mathrm{Fe}(1) \mathrm{Sb}=2.547(1) ; \mathrm{Fe}(2) \mathrm{Sb}=2.530(1) ; \mathrm{N}(2) \mathrm{Sb}$ $=2.042(5) ; \mathrm{N}(1) \mathrm{Sb}=2.045(5) ; \mathrm{N}(2) \mathrm{Si}=1.736(6) ; \mathrm{N}(1) \mathrm{Si}=1.735$ (6); $\mathrm{Fe}(1) \mathrm{SbFe}(2)=121.1(1) ; \mathrm{N}(2) \mathrm{SbFe}(1)=110.2(2) ; \mathrm{N}(1) \mathrm{Sb}-$ $\mathrm{Fe}(1)=110.4(2) ; \mathrm{N}(2) \mathrm{SbFe}(2)=115.5(2) ; \mathrm{N}(1) \mathrm{SbFe}(2)=115.9$ (2); $\mathrm{N}(2) \operatorname{SbN}(1)=74.7(2) ; \mathrm{N}(2) \mathrm{SiN}(1)=91.2(3) ; \mathrm{SiN}(2) \mathrm{Sb}=$ $97.0(3) ; \mathrm{SiN}(1) \mathrm{Sb}=96.9(3)$.

Table III. Summary of Crystal Data, Intensity Collection, and Structure Solution and Refinement for $6 a$ and $6 b$

\begin{tabular}{|c|c|c|}
\hline & $6 a$ & $6 b$ \\
\hline $\begin{array}{l}\text { formula } \\
\text { space group }\end{array}$ & $\begin{array}{l}\mathrm{C}_{21} \mathrm{H}_{29} \mathrm{Fe}_{2} \mathrm{~N}_{2} \mathrm{O}_{6} \mathrm{SbSi} \\
P 2 / n\end{array}$ & $\begin{array}{l}\mathrm{C}_{22} \mathrm{H}_{29} \mathrm{FeMoN}_{2} \mathrm{O}_{7} \mathrm{SbSi} \\
\mathrm{Cc}\end{array}$ \\
\hline cryst syst & monoclinic & monoclinic \\
\hline$a, \AA$ & $10.399(9)$ & 12.305 \\
\hline$b, \AA$ & $16.76(2)$ & $13.812(7)$ \\
\hline$c, \AA$ & $15.74(1)$ & 16.75 \\
\hline$\beta, \operatorname{deg}$ & $94.16(6)$ & 99.0 \\
\hline$Z$ & 4 & 4 \\
\hline$V, \AA^{3}$ & 2736 & 2812 \\
\hline$d_{\text {calc }}, \mathrm{g} / \mathrm{cm}^{3}$ & 1.619 & 1.736 \\
\hline $\begin{array}{l}\text { cryst dimens, } \\
\mathrm{mm}^{3}\end{array}$ & $0.10 \times 0.12 \times 0.20$ & $0.12 \times 0.15 \times 0.25$ \\
\hline radiation & $\mathrm{M}_{\circ} \mathrm{K} \alpha(0.71069 \AA)$ & $\mathrm{M}_{\mathrm{o}} \mathrm{K} \alpha(0.71069 \AA)$ \\
\hline$\mu, \mathrm{cm}^{-1}$ & 20.84 & 19.52 \\
\hline $\begin{array}{l}\text { no. of unique } \\
\text { reflns measd }\end{array}$ & 3374 & 2188 \\
\hline $\begin{array}{c}\text { no. of obsd reflns } \\
\text { for refinement }\end{array}$ & $2923\left(F_{\mathrm{o}}>2 \sigma\left(F_{\mathrm{o}}\right)\right)$ & $2020\left(F_{\mathrm{o}}>2 \sigma\left(F_{\mathrm{o}}\right)\right)$ \\
\hline $\begin{array}{l}\text { variables used in } \\
\text { refinement }\end{array}$ & 323 & 269 \\
\hline$R$ & 0.033 & 0.027 \\
\hline$R_{\mathrm{w}}$ & & 0.033 \\
\hline $\begin{array}{c}w=k /\left(\delta^{2} F+\right. \\
\left.\quad|g| F^{2}\right)\end{array}$ & $\begin{array}{l}k \text {, unit weight; } g \text {, } \\
\text { unit weight }\end{array}$ & $k, 1.0 ; g, 0.00135$ \\
\hline $\begin{array}{l}\text { atoms refined } \\
\text { anisotropically }\end{array}$ & $\begin{array}{l}\mathrm{Sb}, \mathrm{Fe}, \mathrm{Si}, \mathrm{O}, \mathrm{N} \\
\quad \mathrm{C} 1-\mathrm{C} 21\end{array}$ & $\begin{array}{l}\mathrm{Sb}, \mathrm{Mo}, \mathrm{Fe}, \mathrm{Si}, \mathrm{O}, \mathrm{N}, \\
\mathrm{C} 1-\mathrm{C} 7, \mathrm{C} 13, \mathrm{C} 17\end{array}$ \\
\hline
\end{tabular}

the lone pair with the group-15 elements, on going from phosphorus to bismuth, and may be related to an increase in the $\mathrm{s}$ character of the lone pair.

Compounds $6 \mathbf{a}-\mathbf{c}$ have been fully characterized. A comparison of ${ }^{1} \mathrm{H}$ NMR values (Table I) of free, 4 , and complexed, 6, derivatives shows, as expected, ${ }^{2 c}$ a downfield shift of the methyl and tert-butyl resonances as a result of complexation. A downfield shift is also observed for the cyclopentadienyl signal of $6 \mathbf{a}$, whereas the corresponding value for $6 \mathbf{b}, \mathbf{c}$ remains essentially unchanged.

$\mathrm{X}$-ray diffraction studies have been undertaken to confirm the complexation of the lone pair at antimony.

$X$-ray Structural Analysis of $6 a$ and $6 b$. The structures of $6 \mathrm{~b}$ and $6 \mathrm{a}$ are illustrated in Figures 3 and 4 respectively, together with atom-numbering schemes and 
selected bond lengths and angles. Pertinent crystallographic data are summarized in Table III.

Figures 3 and 4 support our assumptions concerning the complexation of the antimony lone pair by $\mathrm{Fe}(\mathrm{CO})_{4}$. The environment around the iron (tetracarbonyl) atom is a distorted trigonal bipyramid in both structures. The largest deviation from ideality is found for the $\mathrm{SbFeC}_{\text {axial }}$ angles: $174.5^{\circ}$ for $6 \mathrm{a}$ and $175.9^{\circ}$ for $6 \mathrm{~b}$. Among the six angles around antimony, only two are far from tetrahedral values: the $\mathrm{FeSbM}$ angles $\left(121.1^{\circ}\right.$ for $6 \mathrm{a}(\mathrm{M}=\mathrm{Fe}), 122.8^{\circ}$ for $6 b(M=M o)$ ) which are larger than the value found in the related compound $7\left(\mathrm{FeSbFe}=117^{\circ}\right)^{8}$ and the

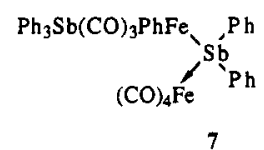

$\mathrm{N}(1) \mathrm{SbN}(2)$ angles which are identical for the free and complexed derivatives $\left(74.3^{\circ}\right.$ for $4 \mathrm{c}, 74.7^{\circ}$ for $6 \mathrm{a}, 74.5^{\circ}$ for 6b). On the other hand, complexation affects the average NSbM angles: $105.3^{\circ}$ for uncomplexed $4 c, 110.3^{\circ}$ and $110.2^{\circ}$ for $6 \mathrm{a}$ and $6 \mathrm{~b}$, respectively.

Another interesting feature of the structure of $\mathbf{6 a}, \mathbf{b}$ is the covalent bond length $\mathrm{Sb}-\mathrm{M}$. If the length is calculated as for $4 c$ (i.e., the sum of the molybdenum covalent radius $\left(1.617 \AA\right.$ ) obtained from $\mathrm{Cp}_{2} \mathrm{Mo}_{2}(\mathrm{CO})_{6}{ }^{7}$ and of the antimony covalent radius $(1.40 \AA))$, the result is $3.017 \AA$, whereas the actual bond length is $2.871 \AA$ for $6 \mathrm{~b}$. Thus, complexation of the antimony lone pair induces a dramatic shortening of the $\mathrm{Sb}-\mathrm{M}$ covalent bond length. This is true also for $6 \mathrm{a}$ since both $\mathrm{Sb}-\mathrm{Fe}$ bond lengths ( $2.547 \AA$ for the covalent bond and $2.530 \AA$ for the dative bond) are almost equal. We have interpreted the shortening of the covalent $\mathrm{Sb}-\mathrm{M}$ bond in terms of an increased amount of $\mathrm{M} \rightarrow \mathrm{Sb}$ $\mathrm{d} \pi-\mathrm{d} \pi$ back-bonding (the similarity of the Sb-N bond lengths in $4 c$ and $6 \mathbf{a}, \mathbf{b}$ argues against any noticeable decrease in the $\sigma$-bonding covalent radius of antimony). This is also consistent with the downfield shift of the cyclopentadienyl resonance observed in the ${ }^{1} \mathrm{H}$ NMR spectrum of $6 \mathbf{a}$ in comparison to $4 \mathbf{a}$.

\section{Experimental Section}

All operations were carried out under an atmosphere of dried nitrogen. Solvents were refluxed over lithium aluminum hydride for 3 days before distillation and kept over sodium wires. $\mathrm{Me}_{2} \mathrm{Si}(\mathrm{N}-t-\mathrm{Bu})_{2} \mathrm{Sb}-\mathrm{Cl}, 1$, and $\mathrm{Me}_{2} \mathrm{Si}(\mathrm{N}-t-\mathrm{Bu})_{2} \mathrm{BiCl}$, 2, were prepared as described in the literature, ${ }^{4}$ as was $3 a-c .{ }^{9}{ }^{1} \mathrm{H}$ NMR spectra were recorded on a Bruker WP-80 instrument. ${ }^{1} \mathrm{H}$ chemical shifts are reported in parts per million relative to $\mathrm{Me}_{4} \mathrm{Si}$. Infrared spectra were recorded on a Perkin-Elmer 883 using one $\mathrm{NaCl}$ cell, the solvent spectrum being subtracted from the complex solution spectrum. Melting points were measured in sealed capillaries. Molecular weight measurements were carried out in benzene.

General Procedure for the Synthesis of $\left[\mathrm{Me}_{2} \mathrm{Si}(\mathrm{N}-t\right.$ $\left.\mathrm{Bu})_{2}\right] \operatorname{EM}(\mathrm{CO})_{n}\left(\eta^{5}-\mathrm{C}_{5} \mathrm{H}_{5}\right), 4 \mathrm{a}-\mathrm{c}$ and 5a-c. Typically a hexane solution of $\left[\mathrm{Me}_{2} \mathrm{Si}(\mathrm{N}-t-\mathrm{Bu})_{2}\right] \mathrm{ECl}\left(\sim 10^{-3} \mathrm{~mol}\right.$ in $\left.30 \mathrm{~mL}\right)$ was added dropwise at room temperature to a suspension of $\mathrm{NaM}(\mathrm{CO})_{n} \mathrm{Cp}$ $\left(\sim 2 \times 10^{-3}\right.$ mole, $70-100 \%$ excess $)$ in hexane $(10 \mathrm{~mL})$. The resulting mixture was magnetically stirred overnight. $\mathrm{NaCl}$ and excess $\mathrm{NaM}(\mathrm{CO})_{n} \mathrm{Cp}$ then were removed by filtration. An extremely air- and moisture-sensitive red solution of $\mathrm{Cp}(\mathrm{CO})_{n} \mathrm{ME}$ $(\mathrm{N}-t-\mathrm{Bu})_{2} \mathrm{SiMe}_{2}, 4 \mathrm{a}-\mathrm{c}$ or $5 \mathrm{a}-\mathrm{c}$, was obtained. According to ${ }^{1} \mathrm{H}$ NMR spectra, yields were nearly quantitative.

Synthesis of 1,3-Di-tert-butyl-2,2-dimethyl-4-[(dicarbonyl- $\eta^{5}$-cyclopentadienyl)ferrio]-1,3,2,4-diazasilastibetidine, $\mathrm{Cp}(\mathrm{CO})_{2} \mathrm{FeSb}(\mathrm{N}-\mathrm{t}-\mathrm{Bu})_{2} \mathrm{SiMe}_{2}, 4 \mathrm{a}$. The solution of $4 \mathrm{a}$ obtained from $0.291 \mathrm{~g}(0.815 \mathrm{mmol})$ of $\mathrm{Me}_{2} \mathrm{Si}(\mathrm{N}-t-\mathrm{Bu})_{2} \mathrm{SbCl}, 1$,

(8) Cane, D. J.; Forbes, E. J.; Hamor, T. A. J. Organomet. Chem. 1976, 117, C101.

(9) Wilkinson, G.; Piper, T. S. J. Inorg. Nucl. Chem. 1956, 3, 104. and $0.277 \mathrm{~g}(1.38 \mathrm{mmol})$ of $\mathrm{NaFe}(\mathrm{CO})_{2} \mathrm{Cp}, 3 \mathrm{a}$, was concentrated under vacuum to $\sim 2 \mathrm{~mL}$ and cooled for $1 \mathrm{~h}$ at $-78{ }^{\circ} \mathrm{C}$. $4 \mathrm{a}$ precipitated as an orange powder $(0.240 \mathrm{~g}, 0.481 \mathrm{mmol}, 59 \%$ yield),

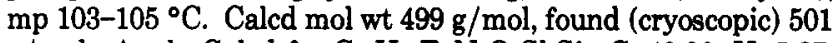
g/mol. Anal. Calcd for $\mathrm{C}_{17} \mathrm{H}_{29} \mathrm{FeN}_{2} \mathrm{O}_{2} \mathrm{SbSi}$ : C, 40.90; H, 5.87; $\mathrm{N}, 5.61$. Found: $\mathrm{C}, 42.49 ; \mathrm{H}, 6.26 ; \mathrm{N}, 4.88$.

Synthesis of 1,3-Di-tert-butyl-2,2-dimethyl-4-[(tricarbonyl- $\eta^{5}$-cyclopentadienyl)molybdenio]-1,3,2,4-diazasilastibetidine, $\mathrm{Cp}(\mathrm{CO})_{3} \mathrm{MoSb}(\mathrm{N}-t-\mathrm{Bu})_{2} \mathrm{SiMe}_{2}, 4 \mathrm{~b}$. The solution of $4 \mathrm{~b}$ obtained from $0.397 \mathrm{~g}(1.11 \mathrm{mmol})$ of $\mathrm{Me}_{2} \mathrm{Si}(\mathrm{N}-t-\mathrm{Bu})_{2} \mathrm{SbCl}$, 1 , and $0.589 \mathrm{~g}(2.20 \mathrm{mmol})$ of $\mathrm{NaMo}(\mathrm{CO})_{3} \mathrm{Cp}, 3 \mathrm{~b}$, was concentrated under vacuum to $\sim 2 \mathrm{~mL}$ and left for 1 day at $-20^{\circ} \mathrm{C}$. $4 \mathrm{~b}$ crystallized as small brown needles $(0.289 \mathrm{~g}, 0.511 \mathrm{mmol}, 46 \%$ yield), $\mathrm{mp} 78-80^{\circ} \mathrm{C}$. Calcd mol wt $567 \mathrm{~g} / \mathrm{mol}$, found (cryoscopic) 569 $\mathrm{g} / \mathrm{mol}$. Anal. Calcd for $\mathrm{C}_{18} \mathrm{H}_{29} \mathrm{MoN}_{2} \mathrm{O}_{3} \mathrm{SbSi}$ : C, 38.11; $\mathrm{H}, 5.16$; $\mathrm{N}$, 4.94. Found: $\mathrm{C}, 38.13 ; \mathrm{H}, 5.33 ; \mathrm{N}, 4.95$.

Synthesis of 1,3-Di-tert-butyl-2,2-dimethyl-4-[(tricarbonyl- $\eta^{5}$-cyclopentadienyl)t tungstenio]-1,3,2,4-diazasilastibetidine, $\mathrm{Cp}(\mathrm{CO})_{3} \mathrm{WSb}(\mathrm{N}-t-\mathrm{Bu})_{2} \mathrm{SiMe}_{2}$, 4c. A 0.520-g (1.46 $\mathrm{mmol}$ ) sample of $\mathrm{Me}_{2} \mathrm{Si}(\mathrm{N}-t-\mathrm{Bu})_{2} \mathrm{SbCl}, 1$, and $0.964 \mathrm{~g}(2.71 \mathrm{mmol})$ of $\mathrm{NaW}(\mathrm{CO})_{3} \mathrm{Cp}, 3 \mathrm{c}$, were reacted to give a solution of $4 \mathbf{c}$, which was concentrated to $\sim 15 \mathrm{~mL}$ and left for $4 \mathrm{~h}$ at room temperature. $4 \mathrm{c}$ was obtained as orange crystals $(0.681 \mathrm{~g}, 1.04 \mathrm{mmol}, 71 \%$ yield), mp 139-141 ${ }^{\circ} \mathrm{C}$. Anal. Calcd for $\mathrm{C}_{18} \mathrm{H}_{29} \mathrm{~N}_{2} \mathrm{O}_{3} \mathrm{SbSiW}$ : C, 32.99; $\mathrm{H}, 4.47 ; \mathrm{N}, 4.28$. Found: $\mathrm{C}, 32.92 ; \mathrm{H}, 4.36 ; \mathrm{N}, 4.25$. One of these crystals was suitable for an X-ray structure determination.

Synthesis of 1,3-Di-tert-butyl-2,2-dimethyl-4-[(dicarbonyl- $\eta^{5}$-cyclopentadienyl)ferrio]-1,3,2,4-diazasilabismuthetidine, $\mathrm{Cp}(\mathrm{CO})_{2} \mathrm{FeBi}(\mathrm{N}-t-\mathrm{Bu})_{2} \mathrm{SiMe}_{2}, 5 \mathrm{a}$. The reaction was carried out with $0.237 \mathrm{~g}(0.533 \mathrm{mmol})$ of $\mathrm{Me}_{2} \mathrm{Si}(\mathrm{NtBu})_{2} \mathrm{BiCl}$, 2 , and $0.203 \mathrm{~g}(1.01 \mathrm{mmol})$ of $\mathrm{NaFe}(\mathrm{CO})_{2} \mathrm{Cp}, 3 \mathrm{a}$, but all attempts to isolate $5 a$ failed. This compound was characterized only by ${ }^{1} \mathrm{H}$ NMR and IR spectra (Table I).

Synthesis of 1,3-Di-tert-butyl-2,2-dimethyl-4-[(tricarbonyl $\cdot \eta^{5}$-cyclopentadienylmolybdenio $]-1,3,2,4-$ diazasilabismuthetidine, $\mathrm{Cp}(\mathrm{CO})_{3} \mathrm{MoBi}(\mathrm{N}-\mathrm{t}-\mathrm{Bu})_{2} \mathrm{SiMe}_{2}, 5 \mathrm{~b}$. The solution of $\mathbf{5 b}$ obtained from $0.38 \mathrm{~g}(0.855 \mathrm{mmol})$ of $\mathrm{Me}_{2} \mathrm{Si}$ $(\mathrm{NtBu})_{2} \mathrm{BiCl}, 2$, and $0.441 \mathrm{~g}(1.65 \mathrm{mmol})$ of $\mathrm{NaMo}(\mathrm{CO})_{3} \mathrm{Cp}, 3 \mathrm{~b}$, was slowly concentrated under vacuum. Small brown needles of $5 \mathrm{~b}$ were deposited on the walls of the flask $(0.308 \mathrm{~g}, 0.47 \mathrm{mmol}$, $55 \%$ yield), mp $130-132{ }^{\circ} \mathrm{C}$. Calcd $\mathrm{mol}$ wt $645.5 \mathrm{~g} / \mathrm{mol}$, found (cryoscopic) $682 \mathrm{~g} / \mathrm{mol}$ (probably because of decomposition). Anal. Calcd for $\mathrm{C}_{18} \mathrm{H}_{29} \mathrm{BiMoN} \mathrm{O}_{3} \mathrm{Si}$ : C, 33.08; $\mathrm{H}, 4.48 ; \mathrm{N}, 4.28$. Found: $\mathrm{C}, 33.14 ; \mathrm{H}, 4.60 ; \mathrm{N}, 4.12$.

Synthesis of 1,3-Di-tert-butyl-2,2-dimethyl-4-[(tricarbonyl- $\eta^{5}$-cyclopentadienyltungstenio]-1,3,2,4-diazasilabismuthetidine, $\mathrm{Cp}(\mathrm{CO})_{3} \mathrm{WBi}(\mathrm{N}-\mathrm{t}-\mathrm{Bu})_{2} \mathrm{SiMe}_{2}, 5 \mathrm{c} . \mathrm{Me}_{2} \mathrm{Si}-$ $(\mathrm{NtBu})_{2} \mathrm{BiCl}, 2(0.418 \mathrm{~g}, 0.941 \mathrm{mmol})$, and $0.655 \mathrm{~g}(1.84 \mathrm{mmol})$ of $\mathrm{NaW}(\mathrm{CO})_{3} \mathrm{Cp}, 3 \mathrm{c}$, were reacted to give a solution of $5 \mathrm{c}$, which was concentrated to $\sim 10 \mathrm{~mL}$ and left for 3 days at $-20^{\circ} \mathrm{C}$. 5c was obtained as red crystals $(0.363 \mathrm{~g}, 0.489 \mathrm{mmol}, 52 \%$ yield). This compound decomposed without melting at $\sim 150^{\circ} \mathrm{C}$ (the color changed from red to black). Anal. Calcd for $\mathrm{C}_{18} \mathrm{H}_{29} \mathrm{BiN}_{2} \mathrm{O}_{3} \mathrm{SiW}$ : C, 29.12; $\mathrm{H}, 3.95 ; \mathrm{N}, 3.77$. Found: C, 29.28; $\mathrm{H}, 4.06$; N, 3.67 .

A single crystal was grown by cooling slowly ( $32 \mathrm{~h}$ ) a solution of $5 \mathrm{c}(\sim 0.1 \mathrm{mmol})$ in hexane $(2 \mathrm{~mL})$ from room temperature to $-20^{\circ} \mathrm{C}$.

General Procedure for the Synthesis of $\left[\mathrm{Fe}(\mathrm{CO})_{4}\right] \mathrm{Cp}$ $(\mathrm{CO})_{n} \mathrm{MSb}(\mathrm{N}-\mathrm{t}-\mathrm{Bu})_{2} \mathrm{SiMe}_{2}, 6 \mathrm{a}-\mathrm{c}$. An hexane solution of $4 \mathrm{a}-\mathrm{c}$ $(\sim 0.5 \mathrm{mmol})$ obtained as described above was evaporated to dryness. The resulting powder was solved in benzene $(20 \mathrm{~mL})$ and used without further purification. This benzene solution was added dropwise to a suspension of $\mathrm{Fe}_{2}(\mathrm{CO})_{9}(\sim 0.5 \mathrm{mmol})$ in benzene $(10 \mathrm{~mL})$, and the resulting mixture was stirred overnight. The dark-red solution thus obtained was filtered to remove small amounts of unsoluble materials and then evaporated to dryness. A relatively air-stable brown powder of $6 \mathrm{a}-\mathrm{c}$ was obtained.

An identical procedure applied to $\mathrm{Cp}(\mathrm{CO})_{3} \mathrm{WBi}(\mathrm{NtBu})_{2} \mathrm{SiMe}_{2}$, $5 c$, did not afford the corresponding complex. $5 \mathrm{c}$ and $\mathrm{Fe}_{2}(\mathrm{CO})_{9}$ were recovered unreacted.

Synthesis of Tetracarbonyl|1,3-di-tert-butyl-2,2-dimethyl-4-[(dicarbonyl- $\eta^{5}$-cyclopentadienyl)ferrio]-1,3,2,4diazasilastibetidineliron, $\left[\mathrm{Fe}(\mathrm{CO})_{4}\right] \mathrm{Cp}(\mathrm{CO})_{2} \mathrm{FeSb}(\mathrm{N}-t$. $\mathrm{Bu})_{2} \mathrm{SiMe}_{2}, 6 \mathrm{a}$. The powder of $6 \mathrm{a}$ obtained from $0.171 \mathrm{~g}(0.479$ $\mathrm{mmol})$ of $\mathrm{Me}_{2} \mathrm{Si}(\mathrm{N}-t-\mathrm{Bu})_{2} \mathrm{SbCl}, 1,0.184 \mathrm{~g}(0.921 \mathrm{mmol})$ of 
$\mathrm{NaFe}(\mathrm{CO})_{2} \mathrm{Cp} \mathrm{3a}$, and $0.171 \mathrm{~g}(0.471 \mathrm{mmol})$ of $\mathrm{Fe}_{2}(\mathrm{CO})_{9}$ was dissolved in a minimum amount of toluene at room temperature; then the solution was cooled at $-20^{\circ} \mathrm{C}$, affording red crystals of $6 \mathrm{a}(0.198 \mathrm{~g}, 0.297 \mathrm{mmol}, 62 \%$ yield based upon 1$), \mathrm{mp} 238-240$ ${ }^{\circ} \mathrm{C}$. Anal. Calcd for $\mathrm{C}_{21} \mathrm{H}_{29} \mathrm{Fe}_{2} \mathrm{~N}_{2} \mathrm{O}_{6} \mathrm{SbSi}$ : C, $37.81 ; \mathrm{H}, 4.39 ; \mathrm{N}$, 4.20. Found: C, 38.21; H, 4.53; N, 4.25.

Some crystals $\left(\sim 10^{-5} \mathrm{~mol}\right)$ were dissolved in refluxing hexane $(25 \mathrm{~mL})$; the solution was filtered, cooled to $0^{\circ} \mathrm{C}$, and left overnight at this temperature, affording red single crystals.

Synthesis of Tetracarbonyl|1,3-di-tert-butyl-2,2-dimethyl-4-[ (tricarbonyl- $\eta^{5}$-cyclopentadienyl) molybdenio] 1,3,2,4-diazasilastibetidineliron, $\left[\mathrm{Fe}(\mathrm{CO})_{4}\right] \mathrm{Cp}(\mathrm{CO})_{3} \mathrm{MoSb}(\mathrm{N}$. $t-\mathrm{Bu})_{2} \mathrm{SiMe}_{2}, 6 \mathrm{~b}$. Hexane $(5 \mathrm{~mL})$ was added to the powder of $6 \mathrm{~b}$ obtained from $0.208 \mathrm{~g}(0.582 \mathrm{mmol})$ of $\mathrm{Me}_{2} \mathrm{Si}(\mathrm{N}-t-\mathrm{Bu})_{2} \mathrm{SbCl}$, $1,0.292 \mathrm{~g}(1.09 \mathrm{mmol})$ of $\mathrm{NaMo}(\mathrm{CO})_{3} \mathrm{Cp}, 3 \mathrm{~b}$, and $0.209 \mathrm{~g}(0.575$ $\mathrm{mmol}$ ) of $\mathrm{Fe}_{2}(\mathrm{CO})_{9}$. The resulting brown suspension was vigorously magnetically stirred and then allowed to settle. Solvent was removed by aid of a pipet, and hot toluene $(3 \mathrm{~mL})$ was added to the unsoluble material. The resulting mixture was filtered to give a red solution, which was cooled overnight at $-20^{\circ} \mathrm{C}$. $6 \mathrm{~b}$ was obtained as red crystals $(0.269 \mathrm{~g}, 0.366 \mathrm{mmol}, 63 \%$ yield based upon 1), $m p$ 230-232 ${ }^{\circ} \mathrm{C}$. Anal. Calcd for $\mathrm{C}_{22} \mathrm{H}_{29} \mathrm{FeMoN} \mathrm{O}_{7} \mathrm{SbSi}$ : C, 35.94; H, 3.98; N, 3.81. Found: C, 36.47; H, 4.06; N, 3.74.

Crystals of $6 \mathbf{b}$ were dissolved in a minimum amount of hot toluene, and the resulting solution was slowly cooled overnight from $100^{\circ} \mathrm{C}$ to room temperature, affording single crystals of $6 \mathrm{~b}$.

Synthesis of Tetracarbonyl 1,3 -di-tert -butyl-2,2-dimethyl-4-[(tricarbonyl- $\eta^{5}$-cyclopentadienyl) tungstenio]1,3,2,4-diazasilastibetidineliron, $\left[\mathrm{Fe}(\mathrm{CO})_{4}\right] \mathrm{Cp}(\mathrm{CO})_{3} \mathrm{WSb}(\mathrm{N}$ $t-\mathrm{Bu})_{2} \mathrm{SiMe}_{2}, 6 \mathrm{c}$. The brown powder of $6 \mathrm{c}$ obtained from 0.201 $\mathrm{g}(0.563 \mathrm{mmol})$ of $\mathrm{Me}_{2} \mathrm{Si}(\mathrm{N}-t-\mathrm{Bu})_{2} \mathrm{SbCl}, 1,0.391 \mathrm{~g}(1.10 \mathrm{mmol})$ of $\mathrm{NaW}(\mathrm{CO})_{3} \mathrm{Cp}, 3 \mathrm{c}$, and $0.201 \mathrm{~g}(0.552 \mathrm{mmol})$ of $\mathrm{Fe}_{2}(\mathrm{CO})_{9}$ was dissolved in toluene $(\sim 15 \mathrm{~mL})$ and cooled at $-20^{\circ} \mathrm{C}$. 6c was obtained as a red powder $(0.273 \mathrm{~g}, 0.332 \mathrm{mmol}, 59 \%$ yield based upon 1), $6 \mathrm{c}$ is not soluble enough in benzene to allow molecular weight measurement; $\mathrm{mp} 227-229^{\circ} \mathrm{C}$. Anal. Calcd for $\mathrm{C}_{22} \mathrm{H}_{29} \mathrm{FeN}_{2} \mathrm{O}_{7} \mathrm{SbSiW}$ : C, 32.10; $\mathrm{H}, 3.56 ; \mathrm{N}, 3.40$. Found: C, 32.62 ; $\mathrm{H}, 3.65 ; \mathrm{N}, 3.42$.
X-ray Studies. Crystal Structure Determinations. Suitable crystals of each compound $4 c, 5 b, 6 a$, and $6 b$ were examined by using similar procedures.

The crystallographic data are summarized in Tables II and III. Unit cell parameters were determined from 18-26 carefully centered reflections in the range $20<2 \theta<25^{\circ}$. Data were collected by using the $\omega-\theta$ scan technique up to a $45^{\circ} 2 \theta$ angle. An empirical absorption correction based on a series of $\psi$ scans was made.

The structures were solved by Patterson and difference Fourier techniques and refined by full-matrix least-squares analysis with anisotropic thermal parameters for all metal, oxygen, nitrogen, and some carbon atoms (see Tables II and III).

All hydrogen atoms were fixed at their carbon atoms and refined together as rigid groups. In $6 \mathrm{~b}$ the $\mathrm{Cp}$ ring $(\mathrm{C}(8)-\mathrm{C}(12))$ was refined as a fixed regular pentagon. One of the tert-butyl groups $(\mathrm{C} 18-\mathrm{C} 20)$ is disordered, so each carbon atom occupies two positions with a half weight.

All calculations were carried out on a DEC Micro VAX II computer using the SHELXS-86 and SHELX-76 programs. ${ }^{11}$

Acknowledgment. We thank the Alexander von Humboldt Foundation for a Postdoctoral fellowship (A.M.C.).

Registry No. 1, 118083-14-0; 2, 118083-15-1; 3a, 12152-20-4; 3b, 12107-35-6; 3c, 12107-36-7; 4a, 126457-14-5; 4b, 126457-15-6; 4c, 126457-16-7; 5a, 126422-15-9; 5b, 126422-16-0; 5c, 126422-17-1; 6a, 126457-17-8; 6b, 126457-18-9; 6c, 126457-19-0.

Supplementary Material Available: Tables of atomic coordinates, bond distances and angles, and the anisotropic temperature values of the atoms of structures $4 c, 5 c, 6 a$, and $6 b(12$ pages); listings of structure factor amplitudes of $4 \mathrm{c}, 5 \mathrm{c}, 6 \mathrm{a}$, and $6 \mathbf{b}$ (28 pages). Ordering information is given on any current masthead page.

(10) Hamilton, W. C. Acta. Crystallogr. 1959, 12, 609.

(11) Sheldrick, G. Program for Crystal Structure Determination, Version SHELX-76 and SHELXS-86.

\title{
Ligand-Field and Charge-Transfer Photochemistry of $\mathrm{M}(\mathrm{CO})_{4}(1,10$-phenanthroline $)(M=\mathrm{Cr}$, Mo, W). Mechanistic Information from High-Pressure Effects
}

\author{
S. Wieland, ${ }^{1}$ K. Bal Reddy, ${ }^{2}$ and R. van Eldik* \\ Institute for Inorganic Chemistry, University of Witten/Herdecke, Stockumer Strasse 10, 5810 Witten, FRG
}

Received October 12, 1989

\begin{abstract}
The pressure dependence of the quantum yield for photosubstitution of $\mathrm{CO}$ in $\mathrm{M}(\mathrm{CO})_{4}\left(1,10^{-}\right.$ phenanthroline) $(M=C r, M o, W)$ was studied at different excitation wavelength in order to resolve the nature of the substitution mechanism operating from the ligand-field and charge-transfer excited states. Irradiation at $366 \mathrm{~nm}$ results in positive volumes of activation (between +6 and $+10 \mathrm{~cm}^{3} \mathrm{~mol}^{-1}$ ) for ligand-field photosubstitution, in agreement with a dissociative substitution mode. Irradiation at $546 \mathrm{~nm}$ results in significantly negative volumes of activation (between -12 and $-14 \mathrm{~cm}^{3} \mathrm{~mol}^{-1}$ ) for charge-transfer photosubstitution in the case of $M=M o$ and $W$, which is interpreted as strong evidence for an associative substitution reaction originating from the MLCT excited state. The corresponding value is small positive for the $\mathrm{Cr}$ complex and ascribed to a dissociative process operating from the charge-transfer excited state.
\end{abstract}

\section{Introduction}

The application of high-pressure kinetic techniques in mechanistic studies on the reactions of inorganic and organometallic complexes in solution has received much

(1) Work performed at the Institute for Physical and Theoretical Chemistry, University of Frankfurt, FRG.

(2) On leave from the Department of Chemistry Osmania University, Hyderabad-500007, India. attention from various groups in recent years..$^{3-6}$ Especially the application of this method in the elucidation of the mechanisms of thermal reactions has been rather successful. We and others ${ }^{7}$ have in recent years investi-

(3) van Eldik, R., Ed. Inorganic High Pressure Chemistry: Kinetics and Mechanisms; Elsevier: Amsterdam, 1986.

(4) Merbach, A. E. Pure Appl. Chem. 1987, 59, 161.

(5) Kotowski, M.; van Eldik, R. Coord. Chem. Rev. 1989, 93, 19.

(6) van Eldik, R.; Asano, T.; le Noble, W. J. Chem. Rev. 1989, 89, 549. 